\title{
The Main Topics of the Lectures for Parents. An Analysis of the Planning Documents of Primary School Teachers
}

Diana-Crina Marin \& Mușata Bocoṣ 


\title{
The Main Topics of the Lectures for Parents. An Analysis of the Planning Documents of Primary School Teachers
}

\author{
Diana-Crina Marin $^{\mathrm{a}^{*}}$, Mușata Bocoș ${ }^{\mathrm{b}}$ \\ a Doctoral School "Education, Reflection, Development”, Babes-Bolyai University Cluj-Napoca, 7 Sindicatelor Street, 400029, Romania \\ ${ }^{b}$ Faculty of Psychology and Educational Sciences, Babes-Bolyai University Cluj-Napoca, 7 Sindicatelor Street, 400029, Romania
}

*Corresponding author: diana.pancu@ubbonline.ubbcluj.ro

Abstract

Keywords: lectures for parents, parenting, the educational program for parents, educational counseling
This study contains an analysis of the main topics of the sessions of counseling and guidance that are offered for the parents. We have identified 46 documents which contain the planning of lectures for parents. The documents were created by primary school teachers from Romania and have been published in the last 10 years on an online platform that is frequently used by primary school teachers. The platform was developed for the optimum experience exchange of the teachers of Romania. We were interested to find out what are the main topics of the lectures for parents and other counseling activities which are frequently held during the collective meetings with parents. We have discovered that most of the lectures for parents could be associated with the following domains: health and balanced nutrition, the impact of New Information and Communication Technologies on children's education, the education of children in the school space, the affective climate and the education of children in the family space, emotional balance and prosocial behaviours, individual and age particularities of the students (learning style, type of intelligence, qualities, abilities, preferences), and school-family collaboration. This study has revealed that at the beginning of the primary school cycle, the most frequent topics of the lectures for parents are: the education of children in the school space and school-family collaboration. At the same time, at the end of the elementary school cycle, the individual and age particularities of the students (learning style, type of intelligence, qualities, abilities, preferences) and the impact of New Information and Communication Technologies on children's development are given special importance.

\section{Schlüsselworte:}

Lektorate für die Eltern, Parenting, Programm der Elternvorbereitung, Erziehungsberatung
Diese Studie beinhaltet eine Analyse der Hauptthemen der Beratungs- und Anweisungssitzungen, die den Eltern angeboten werden. Es wurden 46 Dokumente identifiziert, die die Planung der Lektorate für die Eltern umfassen. Die Dokumente wurden von den Lehrern der Grundschulen aus Rumänien erstellt und in den letzten 10 Jahren auf einer Online- Seite veröffentlicht, die von den Lehrern, die in den Grundschulen unterrichten, häufig benutzt wird. Diese Seite wurde entworfen, um einen Erfahrungsaustausch der Lehrer aus Rumänien zu ermöglichen. Wir waren interessiert zu erfahren, welche die wichtigsten Themen der Lektorate für die Eltern und anderer Beratungstätigkeiten sind, die oft während der Sitzungen mit den Eltern durchgeführt werden. Wir stellten fest, dass die meisten Lektorate für die Eltern mit den folgenden Bereichen verbunden werden könnten: die Gesundheit und die ausgewogene Ernährung, die Auswirkung der neuen Informationstechnologien und der Kommunikation auf die Kinderausbildung, die Ausbildung der Kinder in der Schule, das affektive Klima und die Erziehung der Kinder in der Schule, die emotionale Ausgeglichenheit und die prosozialen Verhalten, individuelle und Altersbesonderheiten der Schüler (Lernstil, Intelligenztyp, Eigenschaften, Fähigkeiten, Vorlieben) und die Zusammenarbeit zwischen der Schule und der Familie. Die Studie zeigt, dass am Anfang der Grundschule die folgenden Themen die häufigsten im Rahmen der Lektorate für die Eltern sind: die Erziehung der Kinder in der Schule und die Zusammenarbeit zwischen der Schule und der Familie. Gleichzeitig wird am Ende der Grundschule eine besondere Bedeutung den individuellen Besonderheiten der Schüler (Lernstil, Intelligenztyp, Eigenschaften, Fähigkeiten, Vorlieben) und der Auswirkung der neuen Informationstechnologien und der Kommunikation auf die Kinderentwicklung gewährt.

Schlüsselwörter: Lektorate für die Eltern, Parenting, Programm der Elternvorbereitung, Erziehungsberatung

\section{Introduction}

This paper contains an analysis of the planning documents elaborated by primary school teachers to offer guidance and adequate support to parents. In the Romanian education system, the lectures for parents are usually organized during the parents' collective meetings. We were interested in finding out which were, for parents, the most important topics tackled in a lecture suggested by primary school teachers. This inventory of themes and activities would be useful to school counselors and primary school teachers interested in offering guidance and support to parents. In Romania, very few studies about the content of the educational programs and lectures for parents have been published. 


\section{Theoretical foundation}

The education for family life is essential since "the relation with the family is an important element of the counseling activity, the family's implication in school life being realized under the form of participation to parents' meetings, lectures, main teaching classes or in any other activity from or outside the curriculum." (Dumitru, 2015, p. 1083). Pedagogical lectures have a decisive role in enhancing actual parental practices. We consider that effective lectures for parents should fulfil similar conditions as interactive and active learning activities. "A good lecturer must have audience appeal, warmth, friendliness, and confidence. He must speak in a voice which is clear and easily understood." (Lunenburg \& Irby, 2011, p. 7). Primary school teachers' activity is very complex. Every teacher who works with elementary school pupils offers services of guidance and counseling to the parents and the children enrolled in his class (Masari, 2010). Nkechi, Ewomaoghene \& Egenti (2016) outline the importance of the role of guidance and counseling activities performed in the school environment. Some of the most important benefits are: helping educational actors to fulfil their whole potential, putting the bases of a strong education, constructing positive behaviours, facilitating school inclusion, developing positive interpersonal interactions and eliminating all the barriers to the children's success in life and at school (Nkechi, Ewomaoghene \& Egenti, 2016; Paisley \& McMahon, 2001; Wilson, Hall \& Hall, 2007). The role of the school counselor and the primary school teacher in developing the actual knowledge and abilities of parents is crucial. Therefore, all the persons involved in children's education should be interested in their continuous improvement and self-training.

The main legislative documents from Romania which contain information about the relationship that should be established between school and family are the Law of National Education (Law no. 1/ 2011) (Legea Educaţiei Naţionale nr. 1/ 2011) and the Framework Regulation for the Organisation and Functioning of the Secondary School Units (approved by Order no. 5079/31.08.2016) (OMENCS nr. 5079/31.08.2016). The study conducted by Marin \& Bocoș (2018), revealed that according to the school principals' and the teachers' opinions, organizing meetings and lectures with the parents is one of the most effective strategies for consolidating the school familypartnership. Bastemur \& Bastemur (2015) considered that online counseling has multiple advantages, but significant challenges can also be encountered. It is unanimously accepted that the family climate and the degree of family involvement in children's education has a decisive influence over the pupil's development (Bodovski \& Youn, 2010). Several Romanian websites provide advice for parents and examples of good practices regarding children's education. For example, the website www.suntpărinte.ro contains, in the section "Primary education" a series of articles regarding the education and the harmonious development of the children that could be used by parents/ primary teachers/ school counselors. One of the factors that emphasize the importance of school guidance and counseling activities realized by primary school teachers is the small number of school counselors in the schools from our country.

\section{Research methodology}

The investigation was conducted between the $1^{\text {st }}$ and the 10th of October, 2019, using the platform www.didactic.ro. This site contains various educational resources created by teachers and is one of the most frequently accessed online platforms by teachers in primary education from our country. We consider that the main advantage for using teaching platforms and other groups on social networks is the exchange of experience and good practices, with a significant impact on the teaching-learning-evaluation processes. The "Advanced search" option was used to identify materials published in primary education in the last 10 years (2009-2019). The following keywords were used: parents (346 results), parent (39 results), lectureship (23 results), meeting with parents ( 77 results) and family (274 results). Among the didactic resources identified there were 46 articles on planning lectures/meetings with parents and 6 projects that included complex activities with parents, known as "parents' school".

\section{Results}

In table no. 1, it can be observed that in the preparatory, I and II classes greater attention is paid to the topics in the fields:

- School-family collaboration;

- The education of children in the school space;

- Health and a balanced nutrition;

- The affective climate and education of children in the family space;

- Emotional balance and prosocial behaviors. 
In the third and fourth grades, the following topics of the lectureships with parents have been included most frequently in the planning carried out by the teachers teaching in primary education:

- The impact of New Information and Communication Technologies on children's education;
- Individual and age particularities of the students (learning style, type of intelligence, qualities, abilities, preferences).

The affective climate and education of children in the family space.

Table no. 1. Topics of the lectures with parents, corresponding to each of the primary school classes

The topic of the lectures
$\begin{aligned} & \text { Health and a balanced nutrition } \\ & \text { The impact of New Information and }\end{aligned}$

Table no. 2 contains the titles of some of the most frequently organized lectures for parents by the primary school teachers in Romania.

Table no. 2. Examples of titles of the lectures for parents

\begin{tabular}{|c|c|}
\hline The topic of lectures & Title of lectures \\
\hline Health and a balanced nutrition & $\begin{array}{l}\text { It matters what, not how much you eat! } \\
\text { Health - the most valuable thing } \\
\text { Hygiene rules and strategies to combat transmissible diseases } \\
\text { The role of daily physical activities } \\
\text { Children's mental health. The effects of intellectual overload on children } \\
\text { Protection in the event of natural disasters } \\
\text { Healthy behaviour and risky behaviour } \\
\text { Road safety education. Accident prevention strategies }\end{array}$ \\
\hline $\begin{array}{l}\text { The impact of New Information and } \\
\text { Communication Technologies on } \\
\text { children's education }\end{array}$ & $\begin{array}{l}\text { The influence of the media on the behaviour and health of the students } \\
\text { The Mobile Phone - A Necessity Or A Muff? } \\
\text { The Internet - friend or foe? } \\
\text { Virtual aggression }\end{array}$ \\
\hline $\begin{array}{l}\text { The education of children in the school } \\
\text { space }\end{array}$ & $\begin{array}{l}\text { The rights and obligations of schoolchildren } \\
\text { The role and importance of extracurricular activities (Stimulating students' creativity } \\
\text { through extracurricular activities) } \\
\text { The importance of participating in school competitions }\end{array}$ \\
\hline $\begin{array}{l}\text { The affective climate and the education of } \\
\text { the children in the family space }\end{array}$ & $\begin{array}{l}\text { Positive discipline (Praise and punishment; Management of parent-child conflicts; } \\
\text { No aggression in the parent-child relationship!; Life without violence!; Prevention } \\
\text { and correction of children's misconduct) Leisure management (Home exercise - a } \\
\text { component of the learning activity; The educational values of leisure activities; } \\
\text { Educational influences exercised by the media; The organization of leisure time; } \\
\text { Quality time spent by parents with children; How we organize children's time on } \\
\text { vacation) } \\
\text { Effective communication - the path to student success in teaching (How to find the }\end{array}$ \\
\hline
\end{tabular}


Emotional balance and prosocial The child's entourage, the friendship relations and the development of the child's

"key" to the child's soul "; The secrets of the power of words)

How to help our children with homework? (The role and implications of homework; Homework - a component of the learning activity)

The key roles of parents in education (The job of being a parent; Rules for being a good parent; The power of the family example)

Parental styles and their consequences

Further reading, a source for the enrichment of the vocabulary (Family friendship starts with reading a book; My child in the world of books)

Strategies for developing the interest in knowing the child

behaviours

The individual and age particularities of the students (learning style, intelligence type, qualities, abilities, preferences)

School-family collaboration social autonomy (Collaboration or competition? How do we teach the child to be a good colleague?)

Volunteering - an act of charity (Let's learn to give!);

Good manners in children (Rules of civilized behaviour); Ways of developing empathy and tolerance

What are the behavioural patterns of children?

How do we help the schoolchild overcome his/her shyness? Emotional management

/ How do we educate the emotional intelligence of children?

The development of self-confidence and self-esteem in schoolchildren

The effects of parental migration on the emotional state of children

Negative student behaviour. The aggression of young school-age children

How well do we know our children? (The qualities, abilities, and aspirations of my

child)

Learning styles (How does your child learn?)

The specificity of my child's age (School ages)

The multiple intelligences of the young school-age student

The collaboration between the school and the family - an essential condition for the teaching act (Family and school - determining factors in the development of the child; Factors that can influence success and failure at school)
Taking into consideration the planning documents that we have analysed and which made reference to the counseling activities published online, it appears that parents are most often asked to complete questionnaires regarding:

- the family climate of the children and the disciplinary techniques used;

- the quality of school-family collaboration;

- the quality of family involvement in school life/children's education;

- children's preferences, abilities, and desires;

- the daily programme of the pupils;

- the carrying out of homework assignments etc.

\section{Discussions}

In the preparatory class, the teachers who teach in the primary education pay special attention to the factors that contribute to a good adaptation of the children to the school requirements and the creation of an authentic partnership between the school and the family. In the first grade, during the sessions and lectures with the parents there were proposed topics that addressed the specificity of the assessment in the primary classes and strategies for carrying out homework. In the second and fourth grades, aspects related to the effective preparation and the content of the National Assessment exams were discussed. In the second, third and fourth grades, the advantages of involving students in as varied as possible extracurricular activities and the risks and advantages of the frequent use of new technologies were debated. Future studies should investigate the opinion of the parents who have pupils enrolled in each level of the primary school system as regards the relevance and utility of each of the lectures topics for parents identified in this research article. The results of these investigations would be very useful in improving the counseling and guidance activity conducted by primary school teachers.

\section{Conclusions}

We have discovered that, at the beginning of the primary school cycle, the most frequent lectures topics for parents were: the education of children in the school space and the school- family collaboration. At the same time, at the end of the elementary school cycle, the individual and the age particularities of the students (learning style and type of intelligence) and the impact that new technologies have on children's development are granted special importance. We have come to the conclusion that some of the lectures for parents are constructed in an interactive manner, which allows parents to participate effectively in activities. Others involve the use of new information and 
communication technologies so as to create more attractive formative and informative learning situations for parents.

\section{Authors note:}

The authors have equal contributions to this article.

Diana-Crina Marin is currently a teacher at "Pavel Dan" Theoretical High School, in Câmpia Turzii and postdoctoral researcher at the Babeș-Bolyai University. Her research areas are aimed to find innovative modalities to consolidate the school-family partnership, considering that the school and family should be real partners regarding children's education. She is also interested in finding the most effective teaching practices that could be successfully used in the educational process.

Muşata Bocoș is a University Professor and Ph.D. Coordinator at the Faculty of Psychology and Sciences of Education (Babeș-Bolyai University, Cluj-Napoca, Romania). In 1997, she obtained a Ph.D. in Educational Sciences, at the Babeș-Bolyai University. Her research interests are reflected in a series of studies and articles published in important national and international journals. Her teaching activity covers several areas, such as the curriculum theory and methodology, general didactics, and educational research.

\section{References}

Bastemur, S., Bastemur, E. (2015). Technology Based Counseling: Perspectives of Turkish Counselors. Procedia Social and Behavioral Sciences, 176, 431-438.

Bodovski, K., Youn, M.J. (2010). Love, discipline and elementary school achievement: The role of family emotional climate. Social Science Research, 39(4), 585-595.

Dumitru, G. (2015). Teacher's Role as a Counsellor. Procedia - Social and Behavioral Sciences, 180, 1080-1085.

Lunenburg, F.C. \& Irby, B.J. (2011). Instructional strategies to facilitate learning. International Journal of Educational Leadership Preparation, 6(4).

Marin, D.-C., Bocoș, M. (2018). School Principals' Opinion on the Strategies of Strengthening School-Family Partnership, The European Proceedings of Social \& Behavioral Sciences EpSBS, LXIII, 544-550, eISSN: 2357-1330.

Masari, A.-G. (2010). Romanian experiences of primary school teachers on school counseling. Procedia - Social and Behavioral Sciences, 2(2), 694-697.

Nkechi, E.E., Ewomaoghene, E.E., \& Egenti, N. (2016). The Role of Guidance and Counselling in Effective Teaching and Learning in Schools. International Journal of Multidisciplinary Studies, I(2), 36-48.

Paisley, O., McMahon, H.G. (2001). School counselling for the 21st century: Challenges and Opportunities. Professional School Counselling, 5(2), 106-110.

Wilson, V., Hall, S., \& Hall, J. (2007). Pupil guidance: An integral part of teacher education and development in Scotland?. Teaching and Teacher Education, 23(7), 11531164.

*** Legea Educaţiei Naţionale nr. 1/ 2011, cu modificările şi completările ulterioare. Available at: http://legeaz.net/legeaeducatiei-nationale-1-2011/ (accessed at 11.11.2019).

*** OMENCS nr. 5079/ 31.08.2016 privind aprobarea Regulamentului-cadru de organizare și funcţionare a unităţilor de învăţământ preuniversitar, text publicat în Monitorul Oficial al României, Partea I, nr. 720/ 19.09.2016. Available https://www.edu.ro/sites/default/files/fisiere\%20articole/Reg ulament\%20cadru.pdf (accessed at 21.10.2019). 